\title{
Imperialism, ANZAC nationalism and the Aboriginal experience of warfare
}

\author{
Padraic Gibson \\ University of Technology Sydney \\ Jumbunna Indigenous House of Learning
}

\begin{abstract}
Aboriginal protest played a key role in undermining the celebratory settler-nationalism of the bicentennial in 1988. In the lead up to another major nationalist mobilisation, the centenary of the Gallipoli invasion on ANZAC Day 2015, extensive official efforts are being made to incorporate Aboriginal experiences into the day, through celebration of the role of Aboriginal people who served in Australia's armed forces.

This article provides a critical analysis of the 2014 NAIDOC theme as a way of exploring some of the tensions in this process. The NAIDOC theme, 'Serving Country: Centenary and Beyond', presented a continuity between Aboriginal soldiers in WW1 and Aboriginal warriors who fought in defence of their land during the $19^{\text {th }}$ Century Frontier Wars.

In contrast, this article argues that the real historical continuity is between the massacres on the frontier, which often involved Aboriginal troopers fighting for the colonial powers, and the invasions undertaken by Australian soldiers in WW1. New research documenting the horrific scale on which Aboriginal people were killed by Native Police in Queensland in the second half of the 19th Century is integrated with studies of the political economy of Australian settler-capitalism in this period. This analysis is used to demonstrate how capitalist class interests drove both the Frontier Wars and the development of an Australian regional empire, which was consolidated by the mobilisation of Australian troops in WW1.
\end{abstract}

\section{Aboriginal people and ANZAC Day}

The Commonwealth Government is making extensive preparations for ANZAC Day on 25 April 2015, marking 100 years since Australian troops invaded Turkey in WW1. This mobilisation of nationalist fervour will rival the 1988 'Australia Day’ celebrations, which marked 200 years since the January 26 invasion of Sydney Cove. In a contribution to the

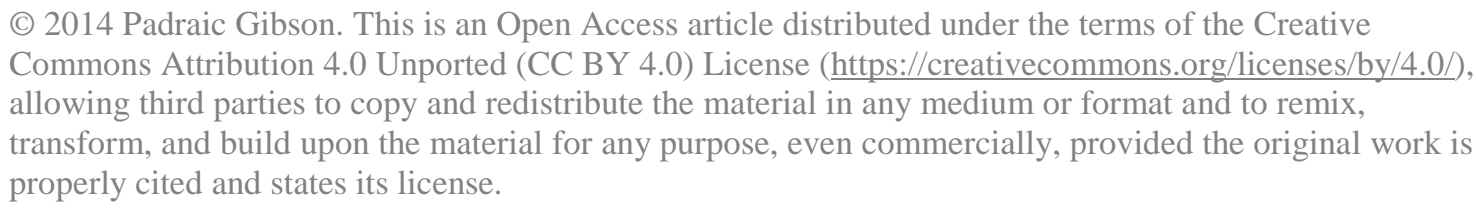

Citation: Cosmopolitan Civil Societies Journal 2014, 6(3): 4190,- http://dx.doi.org/10.5130/ccs.v6i3.4190 
collection of essays What's Wrong with ANZAC, Mark McKenna argues that the 1915 invasion has come to occupy a more serious position in the nationalist pantheon than that of 1788. Mass protests by Aboriginal people and supporters in 1988 seriously tainted January 26, 'undercutting any attempt to present Australia Day as a rallying point for national pride'. Protests had been held on January 26 many times prior and every year since, a consistent dent in Australian nationalism. Prime Minister Bob Hawke began a process of shifting the focal point for celebration of Australian nationalism to ANZAC Day on April 25 in response to these protests. John Howard pushed ANZAC Day even harder, with large-scale funding commitments to reshape teaching, research and entertainment agendas to expand the scale and reach of ANZAC commemoration.

But the elevation of ANZAC has raised its own set of questions about the brutal racism suffered by Aboriginal people throughout Australia's history. Alongside the Howard's ANZAC 'revolution', Aboriginal people who had served in Australia's armed forces became increasingly vocal about the discrimination they suffered. The formation of Indigenous veterans’ associations and advocacy groups, like the Coloured Diggers Group in Redfern, helped to popularise knowledge of this racism; this racism was evident in experiences such as the exclusion of Aboriginal returned service men and women from RSL clubs and honour rolls, the discriminatory restrictions on Indigenous enlistment that persisted into the second half of the 20th Century and apartheid-style conditions that many soldiers were forced to endure when they returned to their communities despite having 'fought for their country' (Korff 2014). A Black Diggers march was started in Redfern in 2007, highlighting the experience of racist exclusion suffered by Indigenous soldiers. Originally it was criticised as being divisive by the RSL (Bibby 2007), but one outcome of the marches has been the approval now of a separate memorial to honour Aboriginal servicemen and women in Hyde Park, set to be unveiled at the 2015 centenary (Taylor 2013).

Humphrey McQueen (2014) argues:

Anxious to bring the Indigenous inside the tent, the War Memorial now stagemanages - after decades of neglect - a special ceremony to honour the Indigenous who served.

Aboriginal activist Ray Jackson, whose father fought in WW2, raised concerns in an opinion piece this year about the extent to which the 'Black Diggers' event was being incorporated 
into settler nationalism, citing the presence of many prominent politicians, the crowd standing twice for the national anthem and the dropping of references to Aboriginal warriors who fought defending their lands from British invasion (Jackson 2014). Jackson's last point highlights the more contentious 'Aboriginal question' that has been raised by the elevation of ANZAC. Why so much focus on wars Australians fought overseas, when the history of warfare on this continent remains largely buried? There are thousands of monuments to Australian warriors that died on foreign shores, but barely a handful marking the systematic massacres of Aboriginal people or their tenacious resistance over a 150 year period from 1788.

The Australian War Memorial promotes a 'rich collection of material relating to Indigenous service men and women', but it has steadfastly refused to include any mention of Frontier Wars within the Memorial (Daley, 2014). Henry Reynolds argues in Forgotten War: 'Aborigines who fought for the white man are given reverence. The many more who fought against him are forgotten' (2013, p. 12). Reynolds book was published specifically as a challenge to include serious remembrance of Frontier Wars through the centenary of ANZAC:

...it will be unconscionable to indulge in a crescendo of commemoration and ignore the fundamental importance of the war between settlers and Indigenous nations in Australia (2013, p. 12).

The 2014 celebrations organised by the National Aboriginal and Islander Day Observance Committee (NAIDOC), made a strong attempt to bridge this divide. NAIDOC is well attended by Aboriginal people and their supporters right across the country. Nakkiah Lui argues (2014) that festivities are shaped by Commonwealth funding and involvement, pushing the focus towards celebration and 'reconciliation' rather than protest. The event poster in 2014 featured artwork showing Aboriginal members of the Australia Army, Navy and Airforce (NAIDOC 2014).

NAIDOC promotional material explained:

This year's NAIDOC theme honours all Aboriginal and Torres Strait Islander men and women who have fought in defence of country.

From our warriors in the Frontier Wars to our warriors who have served with honour and pride in Australia's military conflicts and engagements across the globe. 
We proudly highlight and recognise the role they have played in shaping our identity and pause to reflect on their sacrifice. We celebrate and honour their priceless contribution to our nation.

The defence force itself played a strong role in NAIDOC celebrations across the country. In Brisbane, the ADF was a major sponsor of the community festival attended by many thousands of Aboriginal people, with a prominent recruitment stall. In Perth, the NAIDOC ball had an army theme, with attendees encouraged to wear combat fatigues or other military uniforms.

But this continuity, as presented by the NAIDOC theme, between Aboriginal warriors who fought invasion and those who served in Australia's armed forces, is fundamentally mistaken. There is a real danger of the proud tradition of Aboriginal resistance to British invasion being used bolster the militaristic, nationalist ideology being carefully cultivated through the ANZAC centenary.

This paper will argue that Aboriginal people fighting in defence of their land in the Frontier Wars were challenging the forces of settler capitalist ${ }^{1}$ expansion. In the second half of the 19th Century, when the Frontier Wars were at their peak, the same settler capitalist class, many of whom had built fortunes by slaughtering Aboriginal people and taking their land in the name of the British Empire, began to develop a vision of their own sub-empire in the Pacific. The Australian 'frontier' was pushed further forward in the opening phases of WW1, with Australian forces occupying a number of Pacific Island colonies. The deployment of Australian military alongside broader British Imperial forces in Europe and the Middle East was seen as down-payment on more strident British support for the hegemony of the Australian settler capitalist regime in the South Pacific.

The NAIDOC theme also serves to mask a tragic, confronting and rarely explored fact about the Frontier Wars, that it was Aboriginal people wearing the uniforms of the colonial forces who did some of the heaviest fighting. The history of Aboriginal people in military uniform

\footnotetext{
${ }^{1}$ In a recent literature review, Beilharz \& Cox (2007, p.112) define settler-capitalism as 'the distinctive form that capitalism took in the white settler colonies of the British Empire and the temperate zones of South America... resemblances included an early and significant degree of political autonomy from the imperial power out of which they were established; the early commodification of land and hence labour, with a corresponding absence of a large peasantry ... mass immigration of white settlers from the metropolitan power and the attendant physical and cultural destruction, or at least the brutal subjugation, of indigenous populations. This final characteristic was the original presupposition and condition for all the other features noted.'
} 
does not start with the Boer War, as presented by the NAIDOC promotional material and the growing history of Aboriginal service. As early as the 1830s, a Native Police Force had been established in the new colonial settlement of Port Phillip (Fels 1988), an example soon followed in other colonies. Native Police forces placed Aboriginal people on the front lines of atrocities committed on the expanding frontier right across Australia. Created by parliaments in Sydney, Adelaide and most notoriously in Brisbane, both Native Police troopers and their Aboriginal victims were subject to perhaps the most brutalising process of the Australian colonial experience.

\section{From the Queensland frontier to WW1}

Recent research about the frontier wars in Queensland has demonstrated in graphic detail the slaughter of Aboriginal people on a scale and intensity beyond anything previously considered in Australian acedmic history. The genocide perpetrated upon Aboriginal people in Queensland was almost absolute. Introducing Timothy Bottoms (2013) Conspiracy of Silence, Raymond Evans estimates that more than 250,000 Aboriginal people lived in the area now known as Queensland before colonisation. By WW1 the population had been reduced to less than 20,000 (Bottoms 2013). In a short conference paper in 2014, Evans and Ørsted-Jensen presented research based on newly discovered Native Police files, estimating the number of Aboriginal people directly killed by Native Police attacks in Queensland at 41,000 and the number killed in violent conflict overall at over 60,000.

Bottoms (2013) graphically details the nature of the horrors that were perpetrated. One example given of Native Police atrocities comes from oral history accounts from the Girramay, Jirrbal and Warungu people in North Queensland. Bottoms recounts a story told to him by Ernie Grant, whose grandfather Willy Lee had witnessed the events in question:

The Native Police and settlers surrounded my mum and dad's camp and shot my parents and two brothers. Then we were chained up and marched towards Kirrima station to Horse-swamp Creek.

They rounded the old people up and women and children, and lined them up, children in one line, women in another and the men behind them in line. They then raised the British flag and proceeded to shoot all of the men and smash all the children's heads against tree trunks. Then they raped all the women and shot them, but one (Native Police) trooper went on to have sex with one of the dead 
women. He was unable to withdraw from her body as her pelvis had collapsed and as a result he was shot and left at the site.

Conspiracy of Silence is important not just for its exposure of the horrors that took place in Queensland, but for the way it starts to integrate this research with existing analysis of the political economy of the colony, demonstrating how the slaughter was organised and identifying the interests that were served. Taking this integration further can assist with an understanding of the relationship between the expansion of settler capitalism in the second half of the nineteenth century and the contemporaneous development an Australian imperialism in the South Pacific.

Bottoms cites the work of Bill Thorpe, particularly Colonial Queensland (1996), which includes detailed study of the class interests controlling the state apparatus in Queensland. Thorpe argues that the key figures in the establishment of a new locus of colonial state power in Brisbane in 1859, breaking away from the government in Sydney, were pastoral capitalists, 'many of whom had come North from the New England region of NSW as a ruling class'.

Thorpe (1996, p. 45) cites articles from the contemporary Queensland press to argue:

[T]hose urging separation from NSW in the mid 1850s wanted direct political control, through a Queensland parliament, over the Native Police Force, which was still under the jurisdiction of state officials based in Sydney, so that 'freeholders, occupiers of Crown Land' and 'stockholders' could protect themselves and their property from Aboriginal attacks.

NSW had established a Native Police force in 1848. Before the transition to Queensland control, the white officers of the Native Police were already leading large scale killing missions in the areas now known as Queensland, operating under orders to 'at all times and opportunities to disperse any large assemblages of blacks' (Reynolds 1990, p.53). From 1859, the force reported directly to the Colonial Secretary now ruling the new colony from Brisbane. Under this administration they received a renewed injection of resources and political support, operating as a standing death squad for the next 50 years across the Queensland Frontier.

Leading politician John Douglas, directly responsible for the force when he was Colonial Secretary in 1877-78, said in parliament of the Native Police:

(They) did nothing else but shoot them down whenever they could get at them. That was the sole function of the native police. As far as could be judged from 
the instructions and practice, they were chiefly kept as a military force dispersing natives when they congregated and patrolling districts to drive the blacks into positions where they would not come into contact with the European settlers (Reynolds 2013, p. 119).

When first assembled, the chief concern of the Queensland Parliament was rapid expansion of the pastoral industry. The Council was composed of property owners who had ambitions for more land and excess stock available for quick sale (Bottoms 2013). State coffers could be filled quickly leasing Aboriginal lands. Strict stocking rules ensured that any lease granted must be hastily occupied by large numbers of live-stock. Through the 1860s, as Aboriginal peoples were destroyed at the hands of both the Native Police and settler parties, the Queenslander boasted that 'during no preceding time in the whole history of our colonisation here' had there been 'an equal breadth of new country taken up and stocked in any of the colonies’ (Thorpe 1996, p. 118).

As the new colony became established, these capitalist politicians became the lead actors in a process of economic development still centred on pastoralism, but diversifying into agriculature, mining and commercial and trading services in Brisbane and other coastal centres. Bottoms quotes Thorpe’s description of the hegemony over state power in Queensland held by a nexus around the businessmen Arthur Palmer and Thomas McIlwraith, who were also both Colonial Secretaries through the 1870s and 80s:

The Palmer-McIlwraith alliance either owned, controlled or directed the major economic activities in this period: pastoralism, mining, timber milling, sugar production, banking, shipping, trade, finance, land-speculation, railway construction and the media (Thorpe 1996, p. 159).

In his discussion of this alliance, Thorpe stresses their connections both to international financial interests and 'colonial capitalists' in other Australian capital cities.

Economic historian Philip McMichael (1984) emphasises how by the late 1850s pastoralism in Australia, which had always had a capitalist dynamic, had become a sophisticated enterprise, heavily integrated into international commerce through a process of profound 'urban financial penetration of pastoralism'. This new industry structure emerged from the wake of the 1840s economic crisis, the end of convict transportation and new laws which formally commodified land. Increasingly, land leases were being taken by pastoral companies, 
directly by banks or by powerful individual capitalists heavily enmeshed in broader commercial networks, like those analysed by Thorpe. Pastoralism was a central component of an 'agroindustrial complex' which dominated politics in colonial Australia. It was the expansionist requirements of capital accumulation which pushed the bloody frontier deeper into the North and West of Queensland.

This increasing economic and technological sophistication of pastoral expasion was matched by similar developments in the military force being used to suppress Aboriginal resistance. As Bottoms notes, 'gun technology advanced in the decades following the colonisation of Queensland, and breech-loading Snider carbines (used by the Native Police) were far more effective killing impliments’ (2013, [p. 121]). Evans and Ørsted-Jensen (2014, p.1) say 'during the 1860s, before this conflict had peaked, colonial observers agreed that "hundreds and hundreds were shot every year”'. By the 1870s, they were speaking in terms of 'thousands'.'

Tony Roberts (2009) has described similar processes at work in the Gulf Country of the Northern Territory (NT). Colonial politicians in Adelaide, with extensive business interests in expanding pastoralism, resourced the frightful massacres in the Gulf Country in the early 1880s to secure stolen lands:

These were huge stations, with an average size of almost 16,000 square kilometres. By the end of the year 1881 the entire Gulf district (an area the size of Victoria, which accounted for a quarter of the Territory's pastoral country) had been leased to just 14 landholders, all but two of whom were wealthy businessmen and investors from the eastern colonies... in just four years the Aboriginal population of at least $4000 \ldots$ was dispossessed of every inch of land.

Successful investors included the North Australian Pastoral Company, whose founding member was Premier Mcllwraith discussed above (Beanland 2013) and who still hold leases in the region. The Queensland Native Police undertook regular punitive expeditions across the Western border of Queensland into NT Gulf Country to support the suppression of Aboriginal resistance to this dispossession (Roberts, 2005). The settler-capitalist class which controlled colonial parliaments was becoming increasingly integrated across the Australian continent and self-aware of their distinct interests.

Henry Parkes argued to the Federation Conference in 1890: 
'We must make ourselves a united people and appear before the world as one. The term "going home" must die away... we are "Australian" and rich men remain on the spot' (Federation Conference 1890).

Central to the growth of this class consciousness of 'Australian... rich men', was realisation of the need to make independent calculations about their strategic position in the region. In the second half of the 19th Century there was heavier lobbying of Britain for a more aggressive military posture in the South Pacific (Thompson 1980). The Australians wanted security of trade routes and the maintenance of their own strategic position against other imperial powers increasingly active in the region, especially Germany and France. In 1883, at the height of the massacres of Aboriginal people on the northern frontier, Queensland Premier McIlwraith sent an expedition to plant the Union Jack at Port Moresby and annex New Guinea to Queensland, east of the line demarking Dutch occupation (Overlack 1979). Leading Australian politicians organised a 'Convention of the Colonies', to rally behind his actions.

Will McIlwraith, the Premier's brother, described the rationale behind his action in a newspaper editorial:

The principal objects sought by the present annexation are - the protection of the Australian colonies from the interference or domination of a foreign power, and the conservation of our commercial interests in the Southern Seas and in connection with New Guinea (Thompson 1980, p. 55).

The convention proclaimed an Australian 'Monroe Doctrine... declaring that "Australia cannot be secure if any other power is allowed to establish itself between the Australian coast and South America”' (Thompson 1980, p. 87). Delegates also passed the first resolutions on the need for a federation with explicit powers over Pacific Island colonies. These resolutions reflect some of the concerns that led to the Federation Convention, which eventually lead to a united Australian parliament.

The Queensland action was taken to try and force the hand of the British government, who had refused Australian requests for annexation of New Guinea. The British were worried about provoking a reaction from other imperial powers capable of retaliating in areas they considered more strategically important such as the Middle East. The government in London was also under humanitarian pressure about the implications of a brutal colonial parliament 
like Queensland ruling Indigenous people in New Guinea (Rose, 1959). Arthur Gordon, the High Commissioner on the Western Pacific, wrote he could 'hardly conceive of a government more unfit' for that responsibility than Queensland, who regarded Aboriginal people 'as vermin to be cleaned off the face of the earth' (Thompson 1980, p. 65).

Eventually, after Germany moved to annex the North of New Guinea, the British proclaimed a protectorate over the South of the island. However, the burgeoning Australian ruling class had learnt an important lesson about the need to increase their own independent strength.

In the speech quoted above, Henry Parkes used the humiliating experience of Queensland's retreat from New Guinea to bolster his calls for a federation of all Australian colonies during the 1890 convention:

I have no doubt whatever in my mind... if Australia could have spoken with one voice in the year 1883, New Guinea would have belonged to Australia. Australia ought to be mistress of the Southern Seas. The trade, the commerce... of these groups of rich islands ought to centre in our ports. And with these advantages, we ought to hold mastery of the hemisphere. That is our destiny, and it will come (Munday 1968, p. 115).

This destiny did indeed come, though for full fruition it would have to wait until WW1.

In 1911, as it became obvious war was approaching, the now federated Australian Commonwealth government had drawn up plans for the full realisation of the Australian Munroe doctrine. New scholarship from Douglas Newtown shows they had plans for rapid and far reaching colonial conquest in the South Pacific and South-East Asia including present-day Indonesia and Timor (Newtown 2014).

When war was declared, the Australian government moved immediately to occupy German colonies in the Pacific. Their first action in the war was the deployment of troops to occupy New Guinea. Six Australian soldiers died in fighting near Rabul in New Guinea in the opening battle for the island, along with 30 Germans and 33 New Guineans on the German side (Orsag 2014).

From the beginning, there has been a strain of ANZAC nationalism that that remembers Gallipoli solemnly, but with a strong dose of resentment. It was after all a fruitless campaign 
to further, not any particular Australian interests, but those of the British Empire. ${ }^{2}$ Certainly, Australian troops invaded Gallipoli at British behest and under British command. The Australian politicians who sent these troops to die, however, were no simple dupes of Britain.

The speeches of Prime Minister Billy Hughes at the Paris Peace Conference, for example, show that his government saw the shedding of Australian blood in Europe and the Middle East as a down payment on British and other allied protection of Australian capitalist control of the whole continent and a sub-Empire in the Pacific. Hughes still had troops occupying Islands formally held by Germany. He demanded these territories be subject to Australian laws, including provisions to exclude non-white entry and settlement (Orsag 2014). Hughes played a key role scuttling Japan's attempts to have a racial equality clause in the League of Nations charter. He spoke of Australia's 'Monroe Doctrine in the South Pacific', in the same terms as his forefathers in the 1880s. The islands seized in WW1, while granted formal independence in the second half of the twentieth century, have never come out from under the shadow of Australian colonial control and some now form part of the 'gulag archipelago' warehousing unwanted refugees.

So the Australian capitalist class, who built their fortunes waging genocidal warfare against Aboriginal people to seize the Australian continent, fought WW1 to guarantee a much expanded sphere of influence - to secure an Australian regional empire.

\section{Imperialism and 'Native' soldiers}

Both Frontier Wars and Australian imperialism in the Pacific were part of a global imperialist system dividing up the world in the 19th Century, as industrial capitalism entered a new stage of development and expansion. Every single major European power needed guaranteed access to raw materials and markets for the firms based within their borders. They also coveted the military means to deprive their rivals of access (Harman 2009).

The height of the slaughter in Queensland and the birth of Australian imperialist strategy coincided with a dramatic acceleration in both capitalist development and imperialist competition worldwide. In 1875, only $10 \%$ of Africa was under formal colonial control. In the quarter century to 1900 this figure increased to $90 \%$. A majority of the fighting to secure

\footnotetext{
${ }^{2}$ See for example, Paul Keating's attitude to Gallipoli, discussed by McKenna (2010). 
these colonies was actually done by Africans themselves, who were either conscripted or employed as mercenaries (Harman 2009). A similar strategy of mobilising soldiers drawn from the ranks of colonised people was used for warfare being waged to put down anticolonial insurgency across the world. West Indian regiments composed of former slaves were a garrison force on the islands, but also in West Africa (Richards 2008). The British Raj inherited an army of more than 200,000 Indian soldiers who had fought in the service of the East India company (Rettig \& Hack 2006).

Richards (2008) has shown how colonial administrators who established and maintained Native Police units in Australia studied the British imperial experience of using 'native' soldiers. Others, such as Warburton in South Australia, had active experience commanding native regiments in other colonial contexts (Foster \& Nettleback 2012). Governor Bowen, the first governor of Queensland, named the Malay Corps in Ceylon (now Sri Lanka), the Cape Regiment in the Cape Colony (now South Africa), and the Native units of the Indian army as inspiration for the Queensland Native Police, in letters to the Secretary of State for Colonies (Richards 2008). Using these forces had a number of benefits for the colonial powers in many different settings across the globe, including knowledge of terrain and language and bush skills and ability to survive off the land. One of the main motivations was minimising the cost of colonial war, 'native police forces expected less, were paid less and their overall costs was far less than maintaining European armies’ (Richards 2005, p. 27).

Marie Fels (1988) argues that the establishment of the Port Philip Native Police force in 1837, the first in Australia, was in large part a 'civilising mission' in relation to the Aboriginal people surrounding the new colonial settlement, along with the need to deal with threats to the social order coming from Bushrangers and to a lesser extent Aboriginal 'outrages'. Fels's study is at pains to emphasise the 'positive choice' of the Aboriginal men who joined the force, arguing it is 'story of co-operation'. Recruits were drawn from leaders of local clans, who sought to increase their status and influence both within 'traditional' Aboriginal society and the colonial order and made a collective decision to enter the force. Fels says records of Native Police activities show that these leaders also had some 'success' in their role as troopers, managing to 'mediate' antagonism between white and black, using their position to protect the kin from colonial violence while also increasing their advantages over rival tribal groups distant from Port Phillip. Fels denies that frontier conflict in what is now Victoria 
amounted to a war and says there is no evidence of large scale killing committed by the Native Police.

This interpretation has been challenged, both in terms of the quality of the 'choice' available to Aboriginal people whose way of life had been smashed and in terms of the scale of killings. Whereas Fels' narrative of colonisation of Port Phillip is one of peaceful settlement, Bruce Pascoe writes about a bloody war (Pascoe 2007) and the decimation of Aboriginal livelihood, including the loss of extensively cultivated yam daisy in the space of a couple of years, as grazing sheep destroyed the crop (Pascoe 2014). This strengthens the case of Mackay (2013), that those who joined the police did so 'as captives of a regime which manipulated their minds and controlled their bodies'. Richards (2005) cites numerous scholars who argue the Port Phillip police did commit atrocities, particularly in Gippsland, before demoralisation and sackings led to the disbanding of the force in 1851.

These debates aside, all scholars are in agreement that there was a qualitative difference between the Port Phillip Native Police and the Queensland experience. Most striking is the explicit rationale provided for the various forces - 'keeping the peace' and 'civilising the Natives' in the case of Port Philip, 'shooting them down whenever they could get at them' in the case of Queensland. As argued above, a crucial factor driving these differences is changes to the political economy of pastoralism between the 1840s at the height of the Port Phillip force's activities and the 1860s - 80s which were the 'zenith of the violence' (Bottoms 2013) in Queensland.

This change in function also drove changes in composition of the force itself. In Port Phillip many Native Police were able to remain living with their kin, were given leave for corroborees and hunting and while on patrol were relating to other Aboriginal groups that, in many cases, had long standing tribal relations with their clans. In Queensland, there was an explicit policy to draft recruits from distant southern areas, already decimated by colonisation, and deploy them hundreds of kilometres to the north. Commandant Edric Morisset reported to Colonial Secretary Robert Herbert in 1860, that 'it is absolutely necessary to recruit in a district as far as possible from that in which the men have to serve'. There is some evidence that forces initially deployed outwards from Brisbane used recruits from the Murray and Darling rivers in NSW, whereas operations into the north and west of Queensland came to rely on Aboriginal recruits from the now heavily colonised south east (Richards 2008). There 
was also a policy of ensuring that men from similar tribal groups were separated into different units, to ensure that no Aboriginal group loyalties within the ranks of a unit could compromise the authority of the white officers (Reynolds 1990). In these circumstances, the impact of pre-existing tribal alliances and rivalries on the operations of the Native Police, which are central for Fels’s study of Port Phillip, disappear in the case of Queensland.

Unlike the Port Phillip experience, where extensive records were kept on individual Native Police (Fels, 1988), Richards could find no trace of a staff file for any Aboriginal member of the Native Police in Queensland. There were, however, records to indicate between 900-1000 Aboriginal people served over the 60 year period that the Queensland force was in operation (Richards 2008). This is a similar number to the estimate of Aboriginal people who fought in WW1. Also, unlike Victoria, there are no official records of the recruiting process used to bring troopers into the Queensland force, outside a handful of press reports and snippets of official commentary. Richards argues (2005, p. 160) that any analysis of 'personal motivations (for joining the force) must remain speculative'.

Reynolds argues that Native Police were recruited from a cohort of survivors from dispossessed Aboriginal peoples, 'young men who were learning to survive on the fringes of white society', who had begun unpaid work as labourers and stockmen. He quotes a ‘squatter-politician', commenting in 1858, just before the transfer of power to Queensland, 'it's not wild men we want for troopers, but men broken in by the squatters'. According to Reynolds (1990, p. 75):

While many may have been pressed into the force, there were good reasons for service as troopers, rather than work as 'stockboys'. The Queensland native police pay of $5 \mathrm{~d}$ a day was much less than (white) constables received but it was rare for stockmen to be paid anything at all... they were also better clothed than stockmen or fringe-dwellers and better fed as well.

While recruitment with promises of pay and status was one thing, retaining troopers forced to undertake the brutal work of frontier warfare was quite another. There were mass desertions recorded in virtually every year that the Queensland Native Police were in operation and this was a perpetual source of anxiety amongst colonial administrators. A good indication of how frequent desertions were comes from a 1863 request from Commandant Bligh, who asked permission to recruit eighty troopers, although only fifty were required. The extra number 
was necessary to allow for 'possible desertions and discharges of incurable invalids' (Richards 2005, p. 203). There was a formal policy of executing deserters, though it's unclear how many were carried out (Reynolds 1990). There is also evidence of recruits from the Darling River in 1860 deserting in large numbers before even entering service, who were simply 'recaptured' and pressed into service (Richards 2005).

Richards (2005) cites numerous contemporary reports to demonstrate a widespread fear in the frontier settler populations of the implications of desertions from the Native Police. Partly, racist ideas about inherently ‘savage’ troopers fuelled this anxiety. But Aboriginal people who trained in the use of firearms, deserted with those arms and then moved amongst the insurgent Indigenous populations in the frontier areas, were a real threat to settler life and property. In this sense, some of the Native Police ended up resisting the colonial invasion in a unique way, both by disrupting the recruitment of forces and joining the resistance.

In contrast to Native Police troopers, records exist for all the white officers who were in command of the different Native Police units that made up the Queensland force. Richards (2005) demonstrates that many were intimately connected into the networks of power and patronage of colonial society. But they rode and fought on the frontier with the men they commanded. The fact that 20 of the 150 officers he examines died while serving gives some indication of the fierce nature of this fighting.

When considering the continuity between Australia's frontier wars and imperialist wars abroad, the Boer War is an important turning point. As late as 1902 there is evidence of Native Police killing people in Queensland (Bottoms 2013). In the same year, Lord Kitchener from Britain requested 50 black trackers for the Boer War. The Australian War Memorial say there is evidence in military records of Queensland providing at least four Aboriginal trackers for this purpose (Pianegonda 2014).

The break-up of the Queensland Native Police in the early 20th Century signaled a winding down of heavy military hostilities on the frontier. However, black trackers across Australia continued to be an important auxiliary for regular police work in many places. Well into the 20th Century, this could mean participation in violent raids against Aboriginal people including at Coniston in 1928, where Aboriginal trackers accompanied Gallipoli veteran and 
'Protector of Aborigines' George Murray on a murderous rampage through Warlpiri and Anmatjere country in Central Australia (Midlam 2010).

Despite the rapidly growing body of historical work documenting frontier wars in Australia, there has been no serious academic analysis of the impact that the specific experience of violence perpetrated by the Native Police had on Aboriginal communities. The promise when Native Police enlisted into the Queensland force, was that they would be returned to their home communities once the term of service had passed. However there exists no evidence that this ever took place (Richards, 2005). More likely than making the journey thousands of kilometres home completely unassisted by government is that many of these of the former troopers had to try and make a life in the areas they found themselves once released from service. In the apartheid ‘Aboriginal reserves’ policy that began to operate in Queensland from the late 19th Century, what historian Rosalind Kidd (1997) has described as a system of prisons without walls, it is very likely that at least some of these troopers and their children found themselves living amongst the very tribes they had participated in massacring.

It is hard to conceive of the deep psychological scars left by this particular form of colonial brutality, both for those who did the killing, those who were killed and all of their kin. There has been extensive work done on the psychological and broader social impacts of the trauma associated with conflict on Australia's returned servicemen and women throughout history ${ }^{3}$. For Aboriginal troopers, this trauma would have been compounded by their consistent immersion in the horrible social consequences of the war they prosecuted, having the history of their experience suppressed and having the colonial system they served forcing them to live under a dehumanising regime.

In an intellectual climate where 'traditional', pre-contact, Aboriginal culture is consistently blamed for the extreme rates of contemporary inter-personal violence in some communities (Jarrett 2013), the implications of this trauma demand further investigation. It is hard to conceive of a more violent historical influence on Aboriginal society than the colonial authorities that put guns in the hands of desperate people and ordered them to massacre entire communities in the name of progress and civilisation.

\footnotetext{
3 Twomey (2013) has argued 'Ultimately the traumatising effects of war, and sympathy for its victims, have become a central trope in the post-1980s incarnation of Anzac’.
} 


\section{Invasion then and now}

This article has argued the clear continuity between the war against Aboriginal people on the Australian frontier and the rise of Australian imperialism, including Australia's entry into WW1. What drove both were expansionist needs of the capitalist economy and the particular strategic interests of an emerging Australian settler capitalist class.

Celeste Liddle, responding to the 2014 NAIDOC theme, provided a timely reminder of another continuity - the many leading Aboriginal people who continued to fight for their lands in the 20th Century, while also resisting Australian imperialist interventions overseas. Research by John Maynard (2014) into the Aboriginal experience of WW1 has demonstrated how his grandfather, Fred Maynard, who went on to establish the Australian Aborigines Progressive Association (AAPA), joined his comrades in the Waterside Workers union campaigning against conscription. Liddle (2014) points to the activism of Victorian Aboriginal leader William Cooper in the 1930s, who led a protest march to the German embassy against Kristallnacht and growing Nazi aggression. Cooper went on to oppose the enlistment of Aboriginal soldiers to fight in World War II, arguing 'the Aboriginal now has no status, no rights, no land... nothing to fight for but the privilege of defending a land taken from him... without any compensation or kindness’ (Hoek 2009). Many of the Aboriginal people who led the resurgence of Aboriginal political activism in the early 1970s were active participants in the movement against the Vietnam War. The ferment of struggles for liberation by colonised peoples across the world provided strong inspiration for a radical activism that took forward important struggles of Aboriginal rights, such as Land Rights and the formation of Aboriginal community controlled organisations. These activists identified with the Vietnamese people who were resisting Australian soldiers, and challenged nonIndigenous activists in the anti-war protest movement to move into struggle against the ongoing colonial occupation of the continent they called home (Liddle 2014).

Similarly, when John Howard sent Australian troops (many of them Aboriginal members of Norforce) into Aboriginal communities, a show of force as part of the Northern Territory Intervention, a number of activists who had been drawn into struggle against the Australian invasion of Iraq played an important role organising protest action against the Intervention (Gibson 2012). 
Just as the historic theft of Aboriginal land continues to form the basis of the settler capitalist property regime domestically, Australia remains an imperialist power in the South Pacific (O’Lincoln 2014). The Australian Airforce and Navy dominate the seas and sky, Australian troops and federal police are stationed on islands throughout the region and Australia corporations dominate the regional economy. Since WWII, this position has required the support of the US imperial umbrella in place of the British, and Australian troops have served in many US led wars to secure this support. Indeed the current US-Australian occupation of Iraq will feature strongly in the upcoming ANZAC celebrations. The ruling class in Australia takes their campaign for an imperialist Australian nationalism very seriously indeed.

According to James Brown (2014, p. 19):

All told, the centenary will cost Australian state and federal taxpayers nearly \$325 million. With an additional \$300 million expected in private donations, commemorating the Anzac centenary might cost as much as two-thirds of a billion dollars.

Despite the attempt to incorporate Aboriginal experiences into a celebration of ANZAC, the history of the Aboriginal experience of warfare - on both sides of the Frontier and beyond will continue to pose challenges. But as both the intensity of the official ANZAC ideological campaign and the experience of 1988 show clearly, recognition of this history requires a fight.

\section{References}

Beanland, D. 2013, The Queensland Caesar: Sir Thomas McIlwraith, Boolarong Press, Brisbane. Beilharz, P. \& Cox, L. 2007, 'Settler-capitalism revisited', Thesis Eleven, vol. 88 no. 1 pp 112-124. Bibby, P. 2007, 'It’s been a long walk: blacks unite for march', Sydney Morning Herald, Sydney, Australia, accessed 14 August 2014 http://www.smh.com.au/news/national/its-been-a-longwalk-blacks-unite-for-march/2007/04/16/1176696757591.html

Bottoms, T. 2013, Conspiracy of Silence: Queensland's Frontier Killing Times, Allen and Unwin, Sydney.

Brown, J. 2014, ANZAC's Long Shadow: The Cost of Our National Obsession, Black Inc., Melbourne.

Daly, P. 2014, 'Indigenous Australian's in wartime: It's time to tell the whole story', The Guardian, accessed 16 August 2014 http://www.theguardian.com/commentisfree/2014/jul/07/indigenous-australians-in-wartimeits-time-to-tell-the-whole-story

Evans, R. \& Ørsted-Jensen, R. 2014 'I Cannot Say the Numbers that Were Killed': Assessing Violent Mortality on the Queensland Frontier, Accessed 2 August 2014, http://ssrn.com/abstract=2467836 dio: http://dx.doi.org/10.2139/ssrn.2467836 
'Federation Conference: Sir Henry Parkes in Reply’, 1890, The Evening News, 14 February 1890, pg 5, accessed 29 September 2014, http://trove.nla.gov.au/ndp/del/page/11932435?zoomLevel=1

Foster, R. \& Nettleback, A. 2012, Out of the Silence: The History and Memory of South Australia's Frontier Wars, Wakefield Press, Adelaide.

Gibson, P. 2012, 'Return to the ration days: The NT Intervention, grass-roots experience and resistance', Ngiya: Talk the Law, vol 3, no.5, pp 58-107.

Hansen Fels, M. 1988, Good men and true: the Aboriginal police of the Port Phillip District, 18371853, Melbourne University Press, Carlton.

Harman, C. 2009, A People's History of the World, Verso, London.

Hiery H. 1995, The Neglected War: The German South Pacific and the influence of World War I, University of Hawai'i Press, Honolulu.

Hoek, R. 2009, 'The political impact of WW2 on Aboriginal Australians', Alternative News Network, accessed 1 October 2014, http://forums.altnews.com.au/blogs/ren-hoek/political-impactwwii

Jackson, R. 2014, 'The Black Diggers and Anzac history', On Line Opinion, accessed 14 August 2014 http://www.onlineopinion.com.au/view.asp?article $=16247$

Jarrett, S. 2013, Liberating Aboriginal People from Violence, Connor Court, Ballarat.

Kidd, R. 1997, The Way We Civilise, University of Queensland Press, St. Lucia.

Korff, J. 2014, ‘ANZAC Day Coloured Digger March’, Creative Spirits, web resource accessed 14 August 2014 http://www.creativespirits.info/aboriginalculture/history/anzac-day-coloureddigger-march

Lake, M. 2010, 'How do school children learn about the spirit of ANZAC?', in Lake, M. \& Reynolds, H. (eds), What's Wrong with ANZAC, University of NSW Press, Sydney, pp 135-157.

Liddle, C. 2014, 'We must remember Indigenous warriors who founds war itself', The Guardian, accessed 22 September 2014, http://www.theguardian.com/commentisfree/2014/jul/11/wemust-remember-indigenous-warriors-who-fought-war-itself

Lui, N, 2014, 'Why this year's NAIDOC will be my last', The Guardian, Accessed July 30, 2014, http://www.theguardian.com/commentisfree/2014/jul/15/why-this-years-naidoc-week-willbe-my-last

Maynard, J. 2014, 'The politics of commemorations', Gallipoli to Conniston, conference presentation, Univesity of Technology, Sydney, 28 August, 2014.

Mckenna, M. 2010, ‘ANZAC Day: How did it become Australia’s national day?’, in Lake, M. \& Reynolds, H. (eds), What’s Wrong with ANZAC, University of NSW Press, Sydney, Australia, pp 110-135.

McQueen, H. 2014, 'ANZAC: A class struggle’, Honest History, 3 July 2014, accessed 1 September 2014, http://honesthistory.net.au/wp/mcqueen-humphrey-anzac-a-class-struggle/

McMichael, P. 1984, Settlers and the Agrarian Question: Foundations of Capitalism in Colonial Australia, Cambridge University Press, New York.

Midlam, A. 2010, 'Lest we forget: The Coniston Massacre', On Line Opinion, accessed 1 September 2014, http://www.onlineopinion.com.au/view.asp?article=11211

Munday, B. 1968, Mainstreams in Australian History, Cassell, Melbourne.

Orsag, T. 2014, 'Pacific plunder: Australia's WW1 grab for colonies', Solidarity, accessed 28 July 2014, http://www.solidarity.net.au/australian-imperialism/pacific-plunder-australias-wwigrab-for-colonies/

Overlack, P. 1979, 'Queensland's annexation of Papua : a background to Anglo-German friction' Journal of the Royal Historical Society of Queensland, vol. 10, no.4, pp 123-138. 
Pascoe, B. 2007, Convincing Ground: Learning to fall in love with your country, Aboriginal Studies Press, Canberra.

Pascoe, B. 2014, Dark Emu: Agriculture or accident? Magabala Books, Broome, Western Australia.

Pianegonda, E. 2014, 'Aboriginal soldiers who fought in Boer War deserve greater recognition', $A B C$ News Online, accessed 10 August 2010, http://www.abc.net.au/news/2014-05-30/calls-toidentify-and-honour-aboriginal-soldiers/5489648

O’Lincoln, T. 2014, The Neighbour From Hell: Two Centuries of Australian Imperialism, Interventions, Melbourne.

Rettig, T. \& Hack, K. 2006, Colonial Armies in South-East Asia, RoutledgeCurzon, London.

Reynolds, H. 1990, With the White People: The crucial role of Aborigines in the exploration and development of Australia, Penguin Books, Maryborough.

Reynolds, H. 2013, Forgotten War, NewSouth Publishing, Sydney.

Richards, J. 2005, ‘A Question of Necessity’: The Native Police in Queensland, unpublished PhD Thesis, School of Arts, Media and Culture, Griffith University.

Richards, J. 2008, The Secret War: A True History of Queensland's Native Police, University of Queensland Press, St Lucia.

Roberts, T. 2005, Frontier Justice: A history of the Gulf Country to 1900, University of Queensland Press, St Lucia

Roberts, T. 2009, 'The Brutal Truth: What Happened in the Gulf Country', The Monthly, accessed 15 April 2014, http://www.themonthly.com.au/issue/2009/november/1330478364/tonyroberts/brutal-truth

Rose, J. 1959, The Cambridge History of the British Empire, Cambridge University Press, London.

Taylor, A. 2013, 'Artwork a memorial to Indigenous soldiers', Sydney Morning Herald, Sydney, Australia, accessed 14 August 2014 http://www.smh.com.au/entertainment/art-anddesign/artwork-a-memorial-to-indigenous-soldiers-20131106-2x1mo.html

'Theme and Host City', NAIDOC Website, accessed 2 August 2014 http://www.naidoc.org.au/about/theme-and-host-city

Thompson, R. 1980, Australian Imperialism in the Pacfic: The Expansionist Era 1820-1920, Melbourne University Press, Carlton.

Thorpe, B. 1996, Colonial Queensland: Perspectives of a Frontier Society, University of Queensland Press, St Lucia.

Tobias, R \& Hack, K. (eds), 2006, Colonial Armies in South East Asia, Routledge, London.

Twomey, C. 2013, 'Trauma and the Reinvigoration of ANZAC', History Australia, vol. 10, no. 3, Monash University ePress, Clayton, pp. 85-108. 